\title{
Embryonic and larval development of Labeobarbus megastoma and Labeobarbus platydorsus(pisces: cyprinidae) in lake tana (Ethiopia)
}

\begin{abstract}
The information on the early ontogeny of the endemic Labeobarbus megastoma and Labeobarbus platydorsus fish species of Lake Tana are absent. In this paper we describe for the first time the full developmental sequence from egg to fingerling in controlled conditions. In addition, information on larval behavior, identification and developmental rates are provided. Embryonic development lasted $50: 30 \mathrm{~h}\left(26.3^{\circ} \mathrm{C}\right)$ and $61: 38\left(23.4^{\circ} \mathrm{C}\right)$ for the two species $L$. megastoma and $L$, platydorsus respectively and larval development to the morphology until the fry became very similar to the adult fish lasted 40 days $\left(24.4^{\circ} \mathrm{C}\right)$. The mean total length of the newly hatched larvae of L. megastoma and L. platydorsus were $5.7 \pm 0.03$ and $6.4 \pm 0.03 \mathrm{~mm}$ respectively. The larvae hatched with closed mouth and anus, unpigmented eyes, large yolk and complete yolk absorption and exogenous feeding started on day $10(8.9 \pm 0.07$ and $10.5 \pm 0.12 \mathrm{~mm}$ TL for L. megastoma and L. platydorsus respectively). The first posterior swim bladder aeration completed 5 days and 5 days and 6 $\mathrm{h}$ with $8.4 \pm 0.06$ and $8.2 \pm 0.08 \mathrm{~mm}$ TL for L. megastoma and L. platydorsus respectively and show full juvenile pigmentation and behaviour on the 41 st day.
\end{abstract}

Keywords: Labeobarbus megastoma, Labeobarbus platydorsus, early ontogeny, lake tana, larval behaviour
Volume 9 Issue 5 - 2020

\author{
Belay Abdissa,' Abebe Getahun, ${ }^{2}$ Eshete \\ Dejen $^{3}$ \\ 'Bahir Dar Fisheries and Other Aquatic Life Research Center, \\ Ethiopia \\ ${ }^{2}$ Department of Zoological Sciences Program Unit,Addis Ababa \\ University, College of Natural Sciences, Ethiopia \\ ${ }^{3}$ Agriculture and Environment Division (AED) IGAD Secretariat, \\ Djibouti
}

\begin{abstract}
Correspondence: Belay Abdissa, Bahir Dar Fisheries and Other Aquatic Life Research Center, Bahir Dar, Ethiopia Email epheson2002@gmail.com
\end{abstract}

Received: November 04, 2020 | Published: November 30, 2020

\section{Introduction}

It is pertinent to know embryonic and larval development in different fish species for had better understand their biology in the areas of organ development, nutritional needs and environmental preferences. ${ }^{1}$ Although numerous descriptions of the ontogeny of fish species have been published, and a few studies have summarized the knowledge of the early life histories of fish present specifically areas or regions, information is still lacking many species. ${ }^{2}$ In recent years, evident decrease or even extinction of many local populations of the majority of rheophilic fish species including Labeobarbus megastoma and Labeobarbus platydorsus among the genus Labeobarbus in Ethiopian ichthyofauna has still been observed. Invariably, the major reasons for that situation are seasonal illegal river course blocking gillnet fishery, irrigation and dam construction on the lake tributaries, which are used by barbs as the spawning sites ${ }^{3,4}$ and currently Water hyacinth infestations that block their migration route at the river mouth.

Eggs and developmental studies are useful for understanding of systematic or genetic relationship in identifying spawning site. ${ }^{5}$ Embryology and larval development in cultured fish are also important and evident in aquaculture practices, conservation, rehabilitation and fish production. ${ }^{6}$

The reproductive strategy of the large African cyprinids makes them vulnerable to fishing activities. Generally, they are riverine spawners that form spawning aggregations at river mouths before migrating upstream to spawn on shallow gravel beds during brief periods each year. ${ }^{7,8}$ In Lake Tana out of the 15 Labeobarbus species, seven of them forming $76 \%$ in number, show riverine spawning (ancestral strategy) $^{9-11}$ and the rest eight shows lacustrine spawning (derived strategy), forming $26 \%$ of the labeobarbs in number. ${ }^{9,11}$

L. megastoma and L. platydorsussensu Nagelkerke and Sibbing, 2000 (Cyprinidae: Teleostei) are two of the endemic large African hexploid barb species composing Lake Tana barb species flock. They show riverine spawning (ancestral strategy). ${ }^{9}, 11,12,13$

They have been subjected to overfishing because L.megastoma and $L$. platydorsus were relatively abundant and aggregate at the river mouth during the peak spawning months. ${ }^{11}$

Since Lake Tana resources supports a socio-economically important fisheries subsector in the region. It provides a source of food, job opportunity and cash income, and frequently women and landless youths are major beneficiaries of this activity. The active development of fishery techniques in Ethiopia in the last decades resulted in overfishing. ${ }^{14,15}$ These lead to the drastic decrease of the natural population of the barbs and shifts their conservation status to vulnerable or endangered. ${ }^{16}$ The current situation, thus, demands an immediate development of programs focusing on conservation and restoration of Lake Tana large hexaploid barb species.

Crucial part of any conservation and restoration program for any biological species is investigation of its ontogeny. In Lake Tana, there are some studies concerning early ontogenesis for some species (L. brevicephalus; L.intermedius; small large barbs;). ${ }^{3,17,18}$ The information is scanty and there is a paucity of knowledge on the early life history, first feeding ontogeny and the conservation of Lake Tana large hexaploid barb species. Therefore, this investigation of early developmental stages focused on L. megastoma and L. platydorsus as representatives of Lake Tana piscivore migratory Labeobarbus fish species.

\section{Materials and methods}

\section{Experimental animals}

During the rainy season in 2017 and 2018, two migratory spawners Labeobarbus fish species were collected from the Gumara River, one of the Feeder Rivers of Lake Tana (Figure 1). For identification of the species, we used descriptions and pictures presented by Nagelkerke et 
al. Nagelkerke and Sibbing. ${ }^{12,13}$ According to these authors, the species used types represented in our experiment are L.megastoma (Figure $2 \mathrm{a}$ ) and L. platydorsus (Figure $2 \mathrm{~b}$ ) which are medium to huge sized species inhabiting Lake Tana with maximally $824 \mathrm{~mm}$ and $636 \mathrm{~mm}$ fork length, respectively. Both are shallow bodied fishes, with a clear nuchal hump that rises more gradually. L. megastoma has a small preference for rocky substrates and waters less than $6 \mathrm{~m}$ deep. On the contrary L. platydorsus occurs specifically over muddy and sandy substrates all over the lake, preferably in water deeper than $6 \mathrm{~m} \cdot{ }^{12,13.14}$

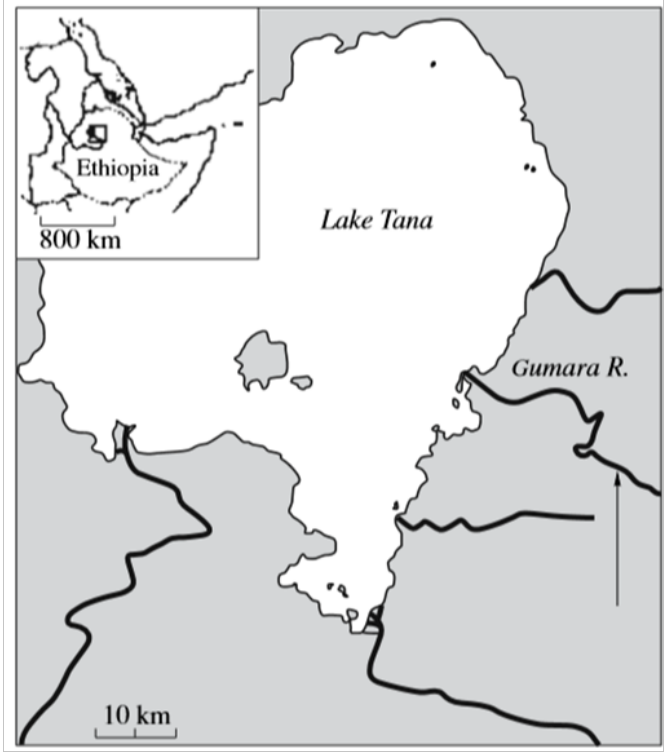

Figure I The sampling sites of studies. The arrow indicates the sampling site.
L. megastoma actively spawns at the beginning of the main rainy season (July to September), whereas L. platydorsus actively spawns at the end of the rainy season (August to October) in the tributaries. However, sporadic spawning was observed in Gumara River and its tributaries over the year. ${ }^{11}$ The presence of fish in tributaries and extended spawning period make L. megastoma and L. platydorsus suitable for obtaining fertilized eggs for further investigation of embryonic and larval development.

\section{Experimental station}

The research was conducted in the laboratory of the Bahir Dar Fishery and Other Aquatic Life Research Center (BFLARC) in nine rectangular glass aquaria free of bottom substrata $(\mathrm{V}=25 \mathrm{l})$. The water temperature in the Gumara River was $20.4-21.2^{\circ} \mathrm{C}$ at night (6-7a.m.) and $20.1-24.4^{\circ} \mathrm{C}$ in the day $(1-2$ p.m.); in its tributary the Ducalit River, it was $19.0-20.7^{\circ} \mathrm{C}$ at night and $23.0-27.8^{\circ} \mathrm{C}$ in the day time. ${ }^{19}$ The eggs and larvae were incubated under a temperature range of 23 $25.8^{\circ} \mathrm{C}$ that corresponds to its natural fluctuations using an electrical thermo-regulating system (Tetratec HT 100 heaters). Dissolved oxygen was kept at $7-8 \mathrm{mg} \mathrm{l}^{-1}$ with continuous aeration and a time clock is used to impose a light period of $12 \mathrm{~h}$ light $12 \mathrm{~h}$ darkness.

\section{Fertilization}

Artificial fertilization was done by dry method. Female was stripped and eggs were collected in Petri dishes with extended mesh walls. Then, the male was also stripped into the Petri dish. Milt was carefully mixed with eggs by dry feathers, then, small volume of water was added. Petri dish was placed on the shallow place in the river for half an hour or more. The fertilized eggs were transferred to BFLARC in plastic bottles with dry cell battery powered aerators attached on it and reared under standard conditions as described in Dzerzhinskii. ${ }^{19}$
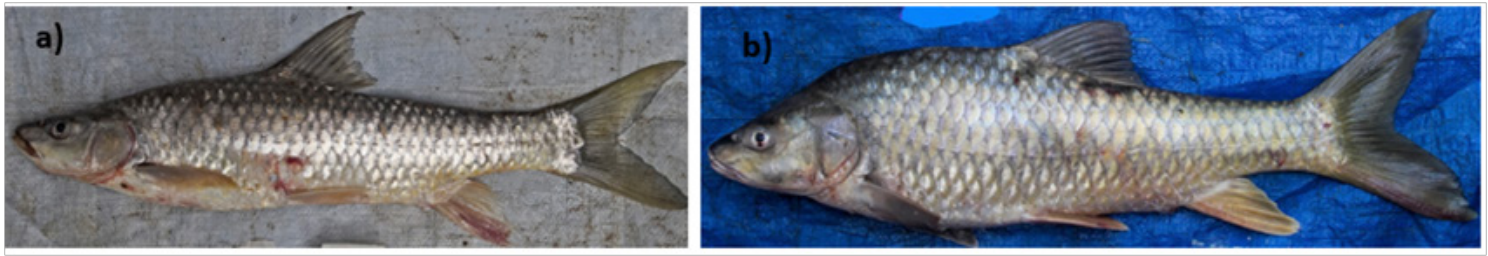

Figure 2 Adult Labeobarbus fish species of Lake Tana: (a) L. megastoma: female; (b) L. platydorsus: female

\section{Incubation of eggs and yolk-sac larvae}

Eggs from each progeny were incubated in the same conditions in separate aquarium. Dead eggs were removed every time from each aquarium. After hatching, larvae were distributed in aquaria: three for each species, with stocking densities of 150 larvae per aquarium. Daily, 5-10 1 of rearing water was replaced with water taken from Lake Tana filtered and UV-treated within 24 hours.

\section{Characterization of the stages of development}

In the present study, L. megastoma and L.platydorsus developmental stages were divided into oocytes, embryonic, postembryonic, larval and post-larval development. The terminologies used for the developmental stages are based on embryonic development in labeobarbus fish. ${ }^{3}$

\section{Sampling and staining}

Five fertilized oocytes were randomly sampled into Petri dish $(n=500)$. Sampled eggs were observed every 30 minutes until hatching and after hatching, larvae were sampled twice a day for observation.
Oocyte, embryonic and larval developmental stages were studied right from unfertilized matured oocytes to fertilization and hatching with stereomicroscopes (euromex Holland). After observations, sampled oocytes were immersed in Bouin's fluid for six hours. Six hours later, the eggs were thoroughly washed with tap water and $70 \%$ ethanol until the yellow color disappeared. Lastly, eggs were stored in $70 \%$ alcohol. The Bouin's solution used was prepared as follows: Picric acid, saturated aqueous solution $75 \mathrm{ml}$; Formalin, $40 \%$ aqueous solution 25ml; Acetic acid, glacial five $\mathrm{ml} .^{20}$ Larvae specimens were fixed in $10 \%$ neutral formalin solution and stained for skeletal structures in alizarin red and Alcian blue. ${ }^{21}$

\section{Image capture and analysis}

Embryonic and larval developments were observed by taking digital images of live and fixed samples. Bouin's fluid fixed embryos were carefully removed after tearing the egg shells due to the opaqueness of the membrane enclosing the egg. Picture was taken by stereomicroscopes (euromex Holland) with an attached digital camera Canon EOS 1100D (72 dpi resolution) and analyzed with Canon Digital Photo Professional Software (Version 3.10.0.0). The 
lidocaine injection B.P. Lox $* 2 \%(\mathrm{NEON})$ was used to immobilize the larva. Measurements of average egg diameter between largest and smallest were done by ocular micrometres (40x magnification) before fixation. Larval total length (TL-length from the tip of snout to the end of the caudal fin; Crawford, 1986) were measured by Matrix electronic digital calipers (precision $=0.01 \mathrm{~mm}$ ). The average mean TL was calculated and recorded.

\section{Results}

\section{Embryonic development}

Embryonic development starts with fertilization and continues up to hatching. When fertilization occurred the eggs have possessed transparent shell with gray spots within the egg shell. The general sequence of the most important events of the embryonic development of the two Labeobarbus species was shown in Table 1and plates $1 \& 2$.

\section{Fertilized egg}

The mature eggs of L. megastoma and L. platydorsus are demersal, single, perfectly spherical, and adhesive, with a smooth, clear and spherical chorion, yellow homogeneous yolk and with no oil globule (Figure 3a). When fertilization occurred the eggs have possessed transparent shell with gray spots within the egg shell. The membrane composed of two layers contained a large quantity of yolk. Immediately after fertilization, the egg began to take up water and swell, then a medium-sized perivitelline space appeared(Figure 3b). The diameter of fully swollen eggs were $1.91 \pm 0.01$ and $1.96 \pm 0.03$ for L. megastoma and L. platydorsus, respectively (Figure 4).

Table I Time and phases of embryonic development of L.megastoma and L. platydorsus

\begin{tabular}{|c|c|c|c|c|c|}
\hline \multirow{2}{*}{ No } & \multirow{2}{*}{ Developmental stage } & \multicolumn{2}{|c|}{ L.megastoma } & \multicolumn{2}{|c|}{ L. platydorsus } \\
\hline & & $\mathbf{T}^{\circ} \mathbf{C}$ & Time & $\mathbf{T}^{\circ} \mathbf{C}$ & Time \\
\hline I & Fertilized eggs & 23.8 & $0: 00$ & 23.4 & $0: 00$ \\
\hline 2 & Blastodisc formation & 23.6 & $\mathrm{I}: 00$ & 23.4 & $\mathrm{I}: 00$ \\
\hline 3 & Cleavage stage & 23.5 & $\mathrm{I}: 30$ to $4: 36$ & 23.1 & $\mathrm{I}: 30$ to $5: 37$ \\
\hline 4 & Blastula stage & 23.9 & $5: 30$ to $7: 30$ & 23.6 & $6: 37$ to $8: 30$ \\
\hline 5 & Gastrula stage & 23.3 & $8: 30$ to $15: 36$ & 23.8 & $9: 30$ to $15: 30$ \\
\hline 6 & Neurulation stage & 23.4 & $16: 30$ to $18: 30$ & 23.9 & $16: 30$ to $18: 30$ \\
\hline 7 & Organ differentiation & 24.4 & $24: 36$ to $50: 52$ & 23.6 & $20: 30$ to $57: 34$ \\
\hline 8 & Movement detection & 24.8 & $32: 26$ & 23.8 & $30: 30$ \\
\hline 9 & Heart beat & 26 & $41: 28$ & 24.1 & $40: 54$ \\
\hline 10 & Hatching stage & 26.3 & $54: 00$ & 23.4 & $62: 34$ \\
\hline
\end{tabular}

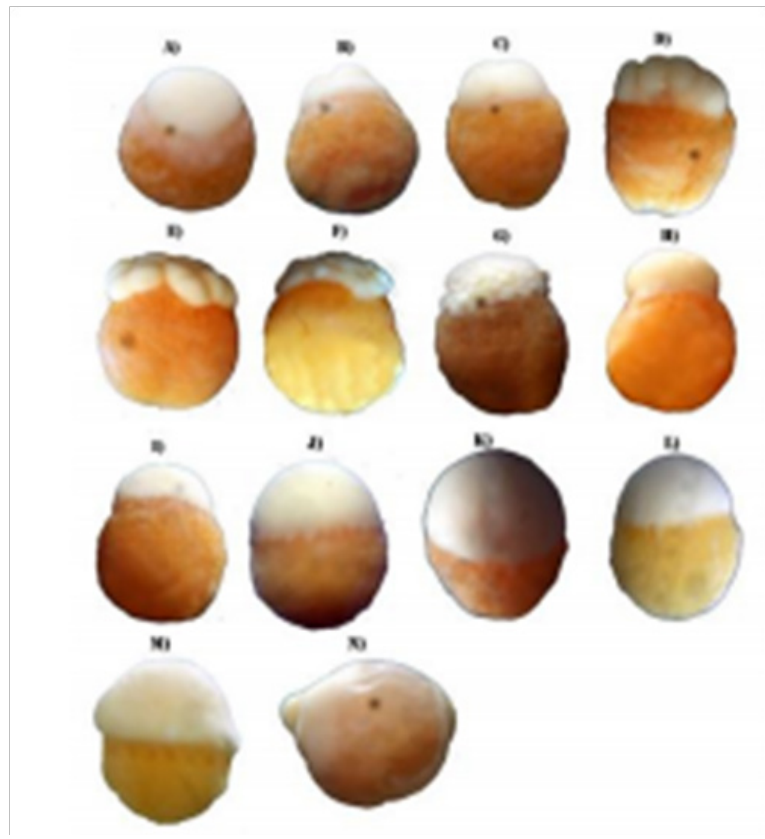

Plate I Photographs representing Bouin's fluid fixed Labeobarbus embryos during embryonic development stages. (A) white dome formation (B) Two cell stage (C) Four-cell stage (D) Eight cell stage (E) Sixteen cell stage; (F) Thirty-two-cell stage; (G) Early morula stage; (H) Late morula stage; (I) Early blastula; (J) Late blastula; (K) Pre early gastrula stage; (L) 30\% epiboly; (M) Mid gastrula; (N) Late gastrula. H- Head portion, T- Tail portion. Magnification: $\times 40$. 


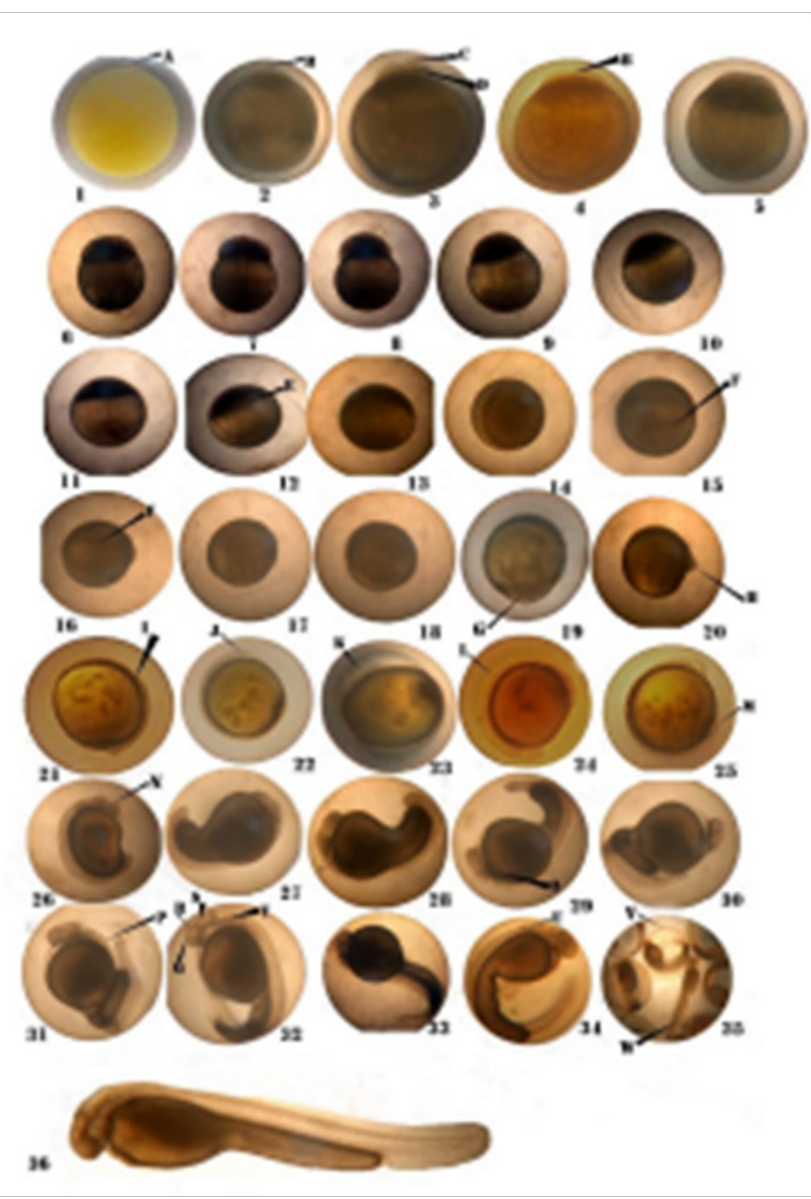

Plate 2 Embryonic development of Lake Tana Labeobarbus: (I) Fertilized egg (A, blastomere); (2) The first cleavage furrow (B, cleavage furrow); (3) 2-cell phase (C, blastoderm: D, blastomere); (4) 4-cell phase; (5) 8-cell phase; (6) I6cell phase; (7) 32-cell phase; (8) Early morula phase; (9) Late morula phase; (10) Early blastula phase; (I I) Mid-blastula phase; (I2) Late blastula phase (E, cells epiboly); (I3) Pre-early gastrula; (14) Early gastrula phase; (I5) 30\% epiboly (F, germ ring); (I6) Mid-gastrula phase (F, germ ring); (I7) Late gastrula phase; (I8) $80 \%$ epiboly; (19) Neural embryo formation (G, blastopore); (20) Blastopore closed/Yolk plug phase ( $\mathrm{H}$, head bud); (2I) Somites appearance (I, somite); (22) Optic vesicle appearance (J, optic vesicle); (23) Optic capsule appearance (K, optic capsule); (24) Notochord appearance (L, notochord); (25) Tail bud appearance (M, tail bud); (26) Otic vesicle appearance (N, otic vesicle); (27) Crystalline lens formation; (28) Movement detection phase; (29) Heart bud appearance (O, heart bud); (30) Heartbeat phase; (3I) Otolith appearance (P, otolith); (32) Cephalization (Q, Fore-brain, R, mid-brain, S, hind- brain, T, vertebrae); (33) Tail free phase; (34) Pectoral fin bud appearance (U, Pectoral fin bud;) (35) Hatching (V, last seconds hatching prophase; W, hatching phase); (36) Newly hatched larva.
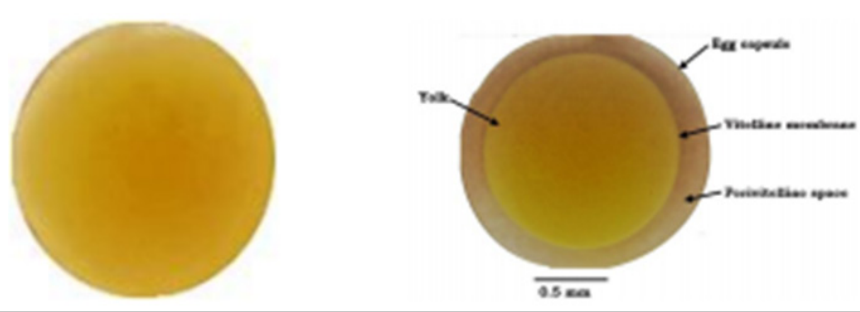

Figure 3 Lake Tana Labeobarbusfish. a) Unfertilized egg a) Fertilized egg structure.

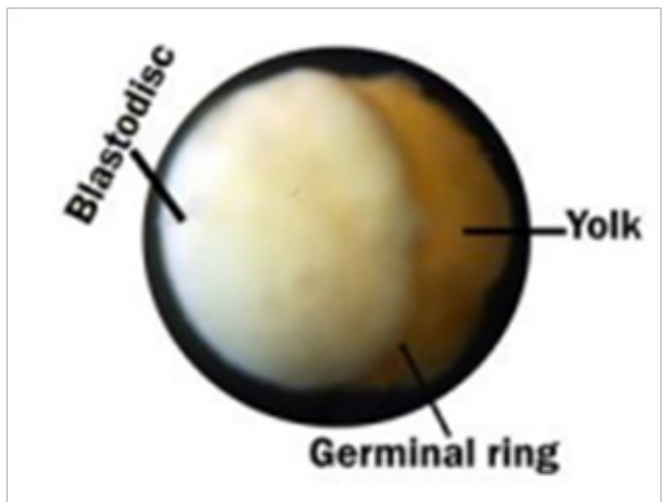

Figure 4 Mid gastrula stage of Lake Tana Labeobarbus fish with germinal ring

\section{Cleavage stages}

Zygote stage ( 1 cell) begins with the fertilization and continues until first cleavage. During this stage, the periviteline space appears (Figure 3b; Plate 1) in $30 \mathrm{~min}$ in L. megastoma whereas in $L$. platydorsus it appears after $1 \mathrm{~h}$ of fertilization. The egg protoplasm moved and aggregated toward the animal pole, forming the primary primordium. The primordium bulged and formed a blastoderm in the shape of a knoll (Plate 1A; Plate 2.1). The blastoderm became thicker as the protoplasm moved.

After fertilization with incubation time of 1 hour and 30 min and 2 hours and $30 \mathrm{~min}$ for L. megastoma and L. platydorsus, respectively, the first cleavage furrow occurred in the top most blastoderm (Plate 2.2). It was dividing the blastodisc into two equal blastomeres (Plate 2.3).The cleavage is typically meroblastic (Plate 1B; Plate.2.3). The second division was meridional and perpendicular to the first cleavage furrow (Plate 1C; Plate 2.4), resulting in four equal blastomeres (Plate $1 \mathrm{C}$; Plate 2.4). The third division was similar and parallel to the first division, eight cells were arranged in two rows of four cells, and the arrangement of the two parallel rows was approximately rectangular (Plate 1D; Plate 2.5). The fourth division was perpendicular to the direction of the first division, and resulted in a 16-cell blastomere (Plate 1E; Plate 2.6).

The cleavage process after fertilization ( 4,8 and 16 cell stages) took 2:30 to $6: 36 \mathrm{hrs}$ and 1:30 to 5:52 hrs for L. megastoma and $L$. platydorsus, respectively (Table 1). As the division proceeded, the size of the blastomere decreased, while the total volume of the cytoplasm remained unchanged (Plate $1 \mathrm{~F}-\mathrm{G}$; Plate 2.7-2.8). At $7 \mathrm{~h}$ and $6 \mathrm{~h}$ after fertilization for L. megastoma and L. platydorsus, respectively, blastoderms were converted into solid cell clusters and boundary lines among cells became indistinct, which signified the formation of morula (Plate 1H; Plate 2.9). At this stage, blastomeres continue to divide synchronously and form a mulberry-like cluster (morula) at the animal pole (Plate $1 \mathrm{H}$; Plate 2.9). The mean diameter of eggs at this stage was $3.01 \pm 0.01$ and $3.38 \pm 0.02 \mathrm{~mm}$ for L.megastoma and $\mathrm{L}$. platydorsus, respectively. At the end of this stage, blastodiscs starts spreading over the yolk (Plate 1 I; Plate 2.10).

\section{Blastula stage}

Along with the successive cleavages, there was a progressive increase in the number of cells with a reduction in size. The beginning of the blastula stage had the transformation of blasto discs to the blastoderm composed of two levels enclosing blastocoel cavity (Plate $1 \mathrm{I}-\mathrm{J}$; Plate 2. 10-12). The mean diameter of eggs was $3.07 \pm 0.01$ and 
$3.38 \pm 0.02 \mathrm{~mm}$ for L. megastoma and L. platydorsus, respectively. About 5:30h and $6: 37 \mathrm{~h}$ post fertilization for the two fish species $L$. megastoma and L. platydorsus, respectively (Table 1), the animal pole formed a cap-like structure atop the yolk, and the morula entered the blastula stage (Plate 1 I; Plate 2.10). At this moment, the crowded cells expand over the yolk and the blastomeres begin to divide asynchronously. In the early blastula stage, the vegetal pole started to shift slightly (Plate $1 \mathrm{I}$; Plate 2.10), and the blastocoele formed as the regular movements of the vegetal pole proceeded (Plate 2.11). At $7 \mathrm{~h}$ and $30 \mathrm{~min}$ and $8 \mathrm{~h}$ and $30 \mathrm{~min}$ post-fertilization of L. megastoma and L. platydorsus, respectively, blastoderm flattened out and began to wrap around the yolk sac (Table 1). Thus, blastoderm entered the late blastula stage (Plate 1J; Plate 2.12).

\section{Gastrula stage}

At this stage, the blastoderm begins invading and slowly spread over the yolk and forms thin layer (Plate 1K; Plate 2.14). Blastoderm cells spread over the yolk and cover about $30 \%$ of it (Plate 2.15). Epibolic cells increase in size. The eggs diameter for L. megastoma and L. platydorsus were about $3.01 \pm 0.01$ and $3.3 \pm 0.03 \mathrm{~mm}$, respectively. Because of epiboly and involution of the blastoderm, the germ ring was completed around the margins of the blastoderm about $8 \mathrm{~h}$ and $30 \mathrm{~min}$ and $9 \mathrm{~h}$ and $30 \mathrm{~min}$ after fertilization for L. megastoma and L. platydorsus, respectively, marking the beginning of the gastrula stage (Plate 2.14). In the early gastrula stage, the blastoderm enclosed approximately $1 / 2$ of the yolk sac. When the blastoderm expanded to cover $2 / 3$ of the yolk sac, the involution of the blastoderm thickened at the margin of the germ ring, and the appearance of the embryonic shield marked the beginning of the middle gastrula stage (Plate 2.16). The mid gastrula stage in the species L.megastoma and L. platydorsus starts at $13 \mathrm{~h} 30 \mathrm{~min}$ and $14 \mathrm{~h}$ and $30 \mathrm{~min}$ post fertilization, respectively. In this stage, the lower rim of the blastoderm thickens and results in a "germinal ring" around the yolk (Plate. 1M; Plate 2.16; Figure 4). The mean diameter of eggs was $3.1 \pm 0.02$ and $3.3 \pm 0.02 \mathrm{~mm}$ for L.megastoma and L. platydorsus, respectively. Blastoderm covered about $3 / 4$ of the yolk sac at $15 \mathrm{~h}$ and $36 \mathrm{~min}$ and $15 \mathrm{~h}$ and $30 \mathrm{~min}$ post-fertilization of L. megastoma and L. platydorsus, respectively, thus marking the onset of the late gastrula stage (Plate. 2.17). The embryonic shield at the animal pole and optic rudiment are visible (Plate 1N; Plate 2.17).

\section{Neurula Stage}

The neural groove began to form in the dorsal midline of the embryo, and the blastoderm entered the neural stage at $17 \mathrm{~h}$ and $30 \mathrm{~min}$ and $16 \mathrm{~h}$ and $52 \mathrm{~min}$ post-fertilization of L.megastoma and L. platydorsus, respectively. During this stage, yolk invasion was completed by gradual spreading over the germ layer, blastoderm covered about $4 / 5$ of the yolk sac. Simultaneously the blastopore and the yolk plug appeared (Plate 2.19). As the epiboly of blastoderm proceeded, the blastopore closed (encircled the yolk) completely $19 \mathrm{~h}$ $30 \mathrm{~min}$ and $18 \mathrm{~h}$ and $30 \mathrm{~min}$ after fertilization, for L.megastoma and $L$. platydorsus, respectively (Plate 2.20).

\section{Organogenesis}

Two somites in the mid-part of the embryos of L.megastoma and L. platydorsus were observed at $23 \mathrm{~h}$ and $36 \mathrm{~min}$ and $20 \mathrm{~h}$ and $30 \mathrm{~min}$ after fertilization, respectively (Plate 2.21). Ten to eleven pairs of somites and an elliptoid optic vesicle were observed in embryos of L.megastoma and L. platydorsus, about $26 \mathrm{~h}$ and $30 \mathrm{~min}$ and $24 \mathrm{~h}$ and $30 \mathrm{~min}$ after fertilization, respectively (Plate 2.22). A pair of kidney- shaped optic capsules became visible in the optic vesicle in embryos of L. megastoma and L. platydorsus at $27 \mathrm{~h}$ and $24 \mathrm{~min}$ and $24 \mathrm{~h} 30 \mathrm{~min}$ after fertilization, respectively.

The caudal region was detached from the yolk mass and became free from embryos of L. megastoma and L. platydorsus at $32 \mathrm{~h}$ and $26 \mathrm{~min}$ and $30 \mathrm{~h}$ and $53 \mathrm{~min}$ after fertilization, respectively (Plate 2.23).The rest most important events of the organogenesis of the two Labeobarbus species were shown in Table 2 and plates 2.25-34.

As the embryonic development was completed, the growing embryo occupied the entire previtelline space; it exhibited frequently vigorous twitching movement by lashing the tail against the chorion that resulted thin chorions. These facilitated the hatching. At this point, the rhythm of the heartbeat was much more rapid, at 90 beats per minute (Plate 2.35).

\section{Hatching of embryos}

As the embryonic development is completed, there is vigorous acceleration of body movements and increasing pushing against the eggshell. After a pause for few seconds, this movement suddenly culminated in a violent jerk where the fully developed embryo began to break and shake off the shell at about $50 \mathrm{~h}$ and $30 \mathrm{~min}$ and $61 \mathrm{~h}$ and $38 \mathrm{~min}$ after fertilization for L. megastoma and L. platydorsus, respectively. Most of the larvae hatched tail first, although some hatched headfirst. The total length of the newly hatched larvae of L. megastoma and L. platydorsus were $5.7 \pm 0.03$ and $6.4 \pm 0.03 \mathrm{~mm}$ immediately after hatching (Plate 2.35;Plate 2.36), larvae lay at the bottom of the glass aquarium and tried to hide in any refuge they could find, usually beneath the remnants of the chorionic membrane.

\section{Larval development}

The pyriform yolk sac of the newly hatched L.megastoma and L. platydorsus larvae were about $5.67 \pm 0.03 \mathrm{~mm}$ and $6.4 \pm 0.03 \mathrm{~mm}$ in TL, respectively. The yolk sac is along the venter of head and body from snout tip to just before anus. The larvae had transparent head and body, lacking melanophores, yolk sac huge (68.8 and 64.5\% TL of L.megastoma and L. platydorsus larvae, respectively) and the head of the larvae were bent toward the yolk sac. The flow of red blood and pectoral finflap were seen in the larvae of L.megastoma and $L$. platydorsus at about $12 \mathrm{~h} 34 \mathrm{~min}$ and $13 \mathrm{~h}$ after hatching, respectively (Table 3).

Two days after hatching, the yolk sac contracted, and the larvae gathered in clusters on the substratum, and periodically underwent rapid tail movements, which moved them haphazardly on the aquarium bottom. At this time remarkable developmental change was seen on the larvae. These are; emergence of tiny knots of growing barbells, nostrils, first light pigmentation occurred in the entire eye, functional pectoral fin development and formation of five-gill arches with well-developed upper and lower jaw but the mouth was still kept closed (Table 3). Therefore, the larvae were still reliant on endogenous nutrients during this period (Figure 6a).

Melanin on the upper part of the head and stomach region of L.megastoma and L. platydorsus larvae were seen at about two days and 7 to $8 \mathrm{~h}$ after hatching, respectively. The translucent nature of the larvae was reduced to slightly opaque. Circulation of pigmented blood could still be seen clearly within the body as it was flowing inside the caudal fins. Full functional upper and lower parts differentiated pumping heart was attained. 
Table 2 Brief descriptions of the most important events of the organogensis of L.megastoma and L. platydorsus

\begin{tabular}{|c|c|c|c|c|c|c|}
\hline \multirow[b]{2}{*}{ No } & \multirow[b]{2}{*}{ Important events } & \multicolumn{2}{|c|}{ L.megastoma } & \multicolumn{2}{|c|}{ L. platydorsus } & \multirow[b]{2}{*}{ Plate } \\
\hline & & $\mathbf{T}^{\circ} \mathbf{C}$ & Time & $\mathbf{T}^{\circ} \mathbf{C}$ & Time & \\
\hline I & Tail bud separation & 27.3 & $26: 30$ & 24.4 & $24: 25$ & (Plate 2.25) \\
\hline \multirow{2}{*}{2} & Otic vesicle appeared behind the optic vesicle, $\mathrm{C}$-shaped embryo encircled with & & & & & \\
\hline & $3 / 5$ yolk sac, $21-22$ somites & 27.3 & $30: 25$ & 23.8 & $27: 47$ & (Plate 2.26) \\
\hline 3 & Crystalline lenses in the optic capsule, $26-28$ pairs of somites & 23.4 & $31: 00$ & 24.1 & $29: 30$ & (Plate 2.27) \\
\hline 4 & $\begin{array}{l}\text { Bulb like embryo bigger head \& stout tail, first obvious contraction of somite- } \\
\text { derived muscle (myotome) } 16 \text { and } 17 \text { wriggling/minutes }\end{array}$ & 23.5 & $32: 26$ & 24.1 & $30: 53$ & (Plate 2.28) \\
\hline 5 & $\begin{array}{l}\text { Synchronized wriggling movements of head and tail regions ( } 2 \text { I-24 wriggling/ } \\
\text { minute) }\end{array}$ & 23.5 & $33: 00$ & 24 & $31: 30$ & \\
\hline 6 & $\begin{array}{l}\text { Complete } 360^{\circ} \text { anticlockwise rotational movement inside the chorion within } 39 \\
\text { and } 38 \text { seconds }\end{array}$ & 23.6 & $36: 00$ & 23.8 & $33: 30$ & \\
\hline 7 & $\begin{array}{l}\text { Embryo elongates, head and tail end differentiated from yolk, tubular rudiments } \\
\text { of heart, 30-33 pairs of somites }\end{array}$ & 23.3 & $36: 16$ & 23.8 & $33: 54$ & (Plate 2.29) \\
\hline 8 & $\begin{array}{l}\text { Three brain vesicles (front, mid and hind brain) with well-defined cephalization, } \\
\text { expansion of neural cord, Heartbeat ( } 45-48 \text { beats/minute), colorless liquid } \\
\text { flowing slowly, paired otoliths, active continuous twitching movement, free tail } \\
\text { length about } 2 / 5 \text { of the embryo length }\end{array}$ & 23.4 & $\begin{array}{l}41: 28- \\
41: 30\end{array}$ & 23.9 & $\begin{array}{l}37: 30- \\
40: 54\end{array}$ & $\begin{array}{l}\text { (Plate 2.30, } \\
\text { Plate 2.31; Plate } \\
\text { 2.32; Plate } 2.33 \\
\text { \&Fig 5) }\end{array}$ \\
\hline 9 & Rudimentary crescent pectoral fin, embryo encircling $2 / 3$ of the yolk sac & 23.4 & $52: 25$ & 23.9 & $49: 54$ & (Plate 2.34) \\
\hline
\end{tabular}

Table 3 Time and landmark of post hatching larval development of L.megastoma and L. platydorsus

\begin{tabular}{|c|c|c|c|c|c|}
\hline \multirow{2}{*}{ No } & \multirow{2}{*}{ Time } & \multicolumn{2}{|c|}{ L.megastoma } & \multicolumn{2}{|c|}{ L. platydorsus } \\
\hline & & Time & TL (mm) & Time & $\mathrm{TL}(\mathrm{mm})$ \\
\hline 2 & Pigmented eye, five-gill arches & $19: 50$ & & $24: 27$ & \\
\hline 3 & Well-developed upper and lower jaw, nostrils formation, emergence of tiny barbells. & 2 day $4 \mathrm{~h}$ & $7.2 \pm 0.02$ & 2 day $6 \mathrm{~h}$ & $7.06 \pm 0.05$ \\
\hline 4 & Melanin on the upper part of the head and stomach region & 2 day $7 \mathrm{~h}$ & $7.2 \pm 0.02$ & 2 day $8 \mathrm{~h}$ & $7.06 \pm 0.05$ \\
\hline 5 & $\begin{array}{l}\text { Operculum formed, } 3 \text { caudal rays, } 10 \text { - } 16 \text { melanophores, posterior swim bladder } \\
\text { began to aerate. }\end{array}$ & 3 day $7 \mathrm{~h}$ & $8.2 \pm 0.04$ & 3 day $7.30 \mathrm{~h}$ & $8.1 \pm 0.05$ \\
\hline 6 & $\begin{array}{l}\text { Posterior swim bladder aeration completed, } 9 \text { caudal fin rays, } 38 \text { upper and } 28 \\
\text { lower pseudo-ribs }\end{array}$ & 5 day & $8.4 \pm 0.06$ & 5 day $6 h$ & $8.2 \pm 0.08$ \\
\hline 8 & Anterior swim bladder development & 9 day $9 \mathrm{~h}$ & & 9 day $12 \mathrm{~h}$ & \\
\hline 9 & Complete yolk sac absorption, Exogenous feeding & Day 10 & $8.9 \pm 0.07$ & Day 10 & $10.5 \pm 0.12$ \\
\hline 10 & Complete separation of dorsal fin, 3 - 4 fin rays, caudal fin bifurcated & Day II & $8.9 \pm 0.06$ & Day II & $10.9 \pm 0.15$ \\
\hline II & 9 dorsal, 18 caudal fin rays were formed & Day 16 & $12.8 \pm 0.29$ & Day 16 & $12.9 \pm 0.33$ \\
\hline 12 & 20 caudal fin, 10 dorsal ray, 6 anal fin rays & Day 24 & $12.7 \pm 0.07$ & Day 24 & $13.5 \pm 0.12$ \\
\hline
\end{tabular}

After three days of hatching, remarkable developmental change was seen on the larvae. These are: Operculum was seen flapping the branchial arch of the larvae, incipient dorsal fin differentiated, some caudal fin rays were formed, mouth opened and the alimentary system became well developed and posterior swim bladder began to inflate. Besides, 10-16 sparse tiny small, round, melanophores on the dorsum of the head and scattered along anterior dorsal surface of the yolk sac was noticed.
Seven days after hatching, anterior swim bladder chamber began to inflate, rudiments of the dorsal fin formed with complete separation from long sheath, and 15 osseous fin rays in the underlobe of the paddle-shaped caudal fin fold appeared (Table 3)(Figure $6 b)$. Pigmentation was more pronounced at this stage. Dorsal some pigment on snout, more on anterior dorsum of heads, over swim bladder and two rows of pigment along the dorsal surface to the caudal area. Lateral mid-lateral row of scattered pigment, subdermal 
pigmentation below auditory capsules, and along the dorsal surface of the intestinal tract. Ventral a few melanophores on anterior and more on the abdominal region, and distinct row from anus to caudal area (Figure 6b).

Ten days after hatching, the yolk sac disappeared completely (Figure 6c) and at this point, appearance of shinning and reflective iris (no more epicanthus covering the eyes), all the larvae were seen actively swimming on the upper surface and the alimentary canal was well developed. The larvae entered the stage of complete reliance on exogenous nutrients, and exogenous feeding was first noted with pellets of excreta (Table 3). Therefore, we refer to them as fry henceforth (Figure 6c).

Sixteen days after hatching, anterior swim bladder chamber was inflated, number of dorsal, caudal fin rays were increased and

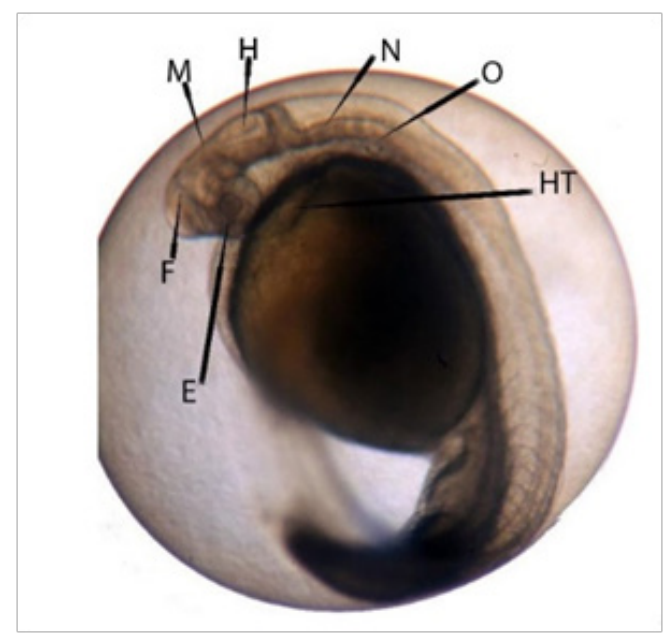

Figure 5 Cephalization phase with three brain vesicles (E: eye; F: front-brain; $\mathrm{H}$ : hind-brain; HT: heart; M: midbrain; N: notochord; O: otolith). a)

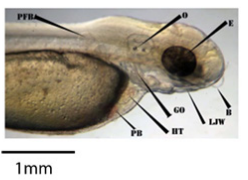

c)

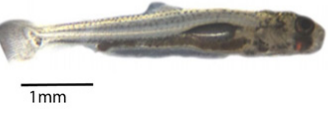

e)

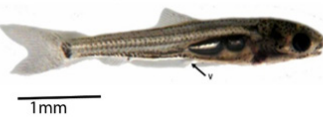

b)

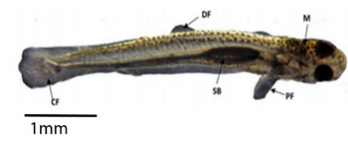

d)

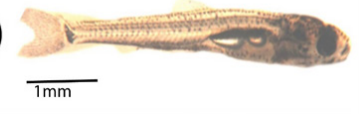

f)

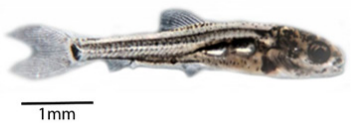

Figure 6 Larval developmental stages of Labeobarbus; (a) 24hr old larvae; (b) 7-day-old larvae; (c) 10 day old larvae; (d) I6-day-old larvae; (e) 24-dayold larvae; (f) $4 \mathrm{I}$ days old larvae. B- barbell, CF- Caudal fin, DF- Dorsal fin, E- eyes, GO- gill opening, HT- heart, LJW- lower jaw, M- Melanin,O- otolith, PB- Pigmented blood, PF- Pectoral fin, PFB- Pectoral fin bud, SB- Swim bladder, V-ventral fin.

\section{Discussion}

In this study, the embryonic and larval development of $L$. megastoma and L. platydorsus reared under artificial conditions were investigated. Research conditions in the experiment were fully controlled rather than ambiental unlike other studies done on other species of Labeobarbus. ${ }^{17,18}$ The variations in temperature might have proved to be an advantage because temperature, filtered water and light conditions were adjusted close to those of the natural environment. rudiments of the anal fin appeared. These caused the fry to behave agilely (Table 3)(Figure 6d).

Twenty-four days after hatching, rudiments of the ventral fin were formed, and the shape of the upper and lower lobes of the caudal fin was almost identical with numeral increments of unpaired fins (dorsal, anal fins and caudal fins (Table 3) (Figure 6e).

Forty-one days after hatching, only a few fin folds existed on the ventral and caudal peduncle. Concerning pigmentation; Dorsalheart-shaped pigment pattern on the dorsum of heads, 10-12 scattered pigment on the snout and two distinct, rows of pigment along the dorsal surface. Lateral more pigment behind eyes, and scattered along upper $25 \%$ of lateral surfaces and along the dorsal surface of the intestinal tract, with scattered pigment on caudal fin. At this stage, the fry was morphologically like adult fish (Figure 6f).

The embryogenesis of L. megastoma and L. platydorsus took a long duration, which agrees with $L$. brevicephalus, ${ }^{3}$ Barbus intermedius, ${ }^{17}$ Pseudorasbora parva, ${ }^{22}$ African small Barbus B. anoplus ${ }^{23}$ and $B$. trevelyani. ${ }^{24}$

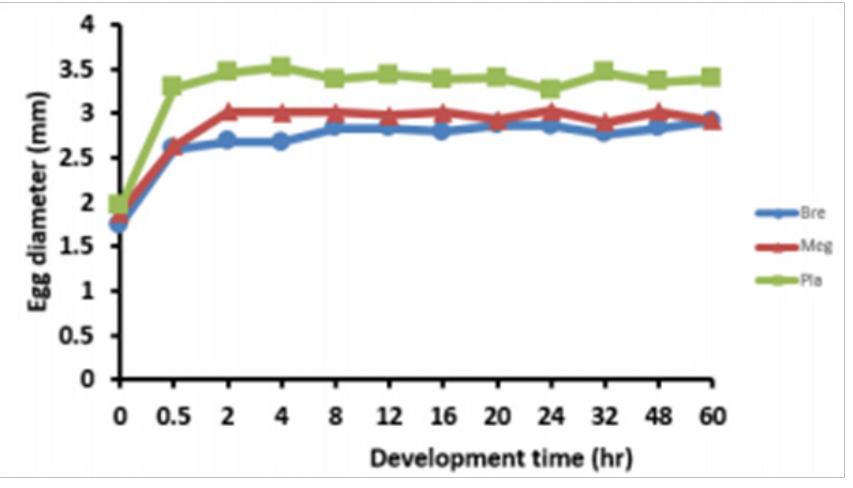

Figure 7 Egg diameterVS Developmental timing of L.megastoma, L. platydorsus and $L$. brevicephalus.

Previously Belay et al. ${ }^{3}$; Alekseyev et al. ${ }^{18}$ and Ryabov ${ }^{17}$ worked on embryonic and larval development of $L$. brevicephalus, spawning of hexaploid large barbs and developmental aspects of L. intermedius in Lake Tana. The present study on the embryonic and larval development of these endemic species provides additional information on larval behavior, identification and developmental rates. Table 4 compares a few developmental stages of the five species $L$. intermedius ${ }^{17}, L$. brevicephalus, L. megastoma, L. platydorsus and P. parva.

Comparisons of average egg diameter vs. developmental timing among L. brevicephalus, L. megastoma and L. platydorsus were shown on Figure 7. Similarly, comparisons of a few developmental traits with African small Barbus ontogeny of B. anoplus, B. trevelyani and small cyprinid fish $P$. parva is given in Table 5.

The fertilized eggs of L. megastoma and L. platydorsus were perfectly spherical, adhesive and demersal with a smooth, clear and spherical chorion, and a homogeneous yolk and yellow without an oil globule. These characteristics are identical with L. brevicephalus ${ }^{3}$ and L. intermedius ${ }^{17}$ (Table 5).

The diameter of unfertilized eggs of L. megastoma and $L$. platydorsus ranged from 1.8 to $2.0 \mathrm{~mm}$ and $1.8 \mathrm{~mm}$ to $2.1 \mathrm{~mm}$, respectively, and that of $L$. brevicephalus and $L$. intermedius were 1.63 to $1.93 \mathrm{~mm}$ and $1.75 \mathrm{~mm}$, respectively. The diameter of the swelled envelope in fertilized eggs in L. megastoma and L. platydorsus were $2.63 \pm 0.03$ ) and $3.29 \pm 0.03) \mathrm{mm}$, respectively. These are slightly different from results of other Labeobarbus spp. from Lake Tana 
Labeobarbus reported by Belay et al., ${ }^{3}$ for $L$. brevicephalus, which is $3.03 \mathrm{~mm}$ and Ryabov ${ }^{17}$ for L. intermedius, which is $3.0 \mathrm{~mm}$ (Table 5). This index varies between the two species and among other fish species. The diameter of the fertilized eggs was bigger as compared to P. parva $1.75 \mathrm{~mm}$, most Perciformes $(0.7 \mathrm{~mm})$ and Cyprinus carpio (1.5 to $2.5 \mathrm{~mm})$. Whereas diameter of fertilized eggs of L. megastoma was smaller as compared to Catostomus commersoni $(2.50$ to $3.03 \mathrm{~mm})$ and white suker $(2.78$ and $3.19 \mathrm{~mm}){ }^{25-28}$ These differences might be due to species-specific characters, incubation temperature, and water

Table 4 Time and phases of embryonic development L.intermedius,L.brevicephalus, L.megastoma, L. platydorsus from Lake Tana and P. parva(from fertilization to hatching)

\begin{tabular}{|c|c|c|c|c|c|c|}
\hline \multirow{2}{*}{ No } & \multirow{2}{*}{$\begin{array}{l}\text { Developmental } \\
\text { stage }\end{array}$} & $\begin{array}{l}\text { P. parva at } \\
24 \pm 1{ }^{\circ} \mathrm{C}\end{array}$ & $\begin{array}{l}\text { L.brevicephalus } \\
\text { (Belay et al., 20 I7) } \\
23.0-25.8^{\circ} \mathrm{C}\end{array}$ & $\begin{array}{l}\text { L.intermedius(Ryabov, } \\
\text { 2002) }\end{array}$ & $\begin{array}{l}\text { L.megastoma } \\
\text { (this study) }\end{array}$ & $\begin{array}{l}\text { L.platydorsus } \\
\text { (this study) }\end{array}$ \\
\hline & & Time & Time & Time & Time & Time \\
\hline I & Fertilized eggs & $0: 00$ & $0: 00$ & $0: 00,22.2^{\circ} \mathrm{C}$ & $0: 00,23.8^{\circ} \mathrm{C}$ & $0: 00,23.4^{\circ} \mathrm{C}$ \\
\hline 2 & Blastodisc formation & $0: 34$ & $\mathrm{I}: 15$ & $\mathrm{I}: 10,22.2^{\circ} \mathrm{C}$ & $\mathrm{I}: 00,23.6^{\circ} \mathrm{C}$ & $\mathrm{I}: 00,23.4^{\circ} \mathrm{C}$ \\
\hline 3 & Cleavage stage & $0: 54$ to $3: 30$ & I:28 to $4: 47$ & $\begin{array}{l}\text { I:35 to } 4: 20 \\
23.3^{\circ} \mathrm{C}\end{array}$ & $\begin{array}{l}\text { I:30 to } 4: 36 \\
23.5^{\circ} \mathrm{C}\end{array}$ & $\begin{array}{l}\text { I:30 to } 5: 37 \\
23.1^{\circ} \mathrm{C}\end{array}$ \\
\hline 4 & Blastula stage & $3: 44$ to $6: 49$ & $5: 15$ to $7: 14$ & $\begin{array}{l}4: 35 \text { to } 6: 20 \\
24.0^{\circ} \mathrm{C}\end{array}$ & $\begin{array}{l}5: 30 \text { to } 7: 30 \\
23.9^{\circ} \mathrm{C}\end{array}$ & $\begin{array}{l}\text { 6:37 to } 8: 30 \\
23.6^{\circ} \mathrm{C}\end{array}$ \\
\hline 5 & Gastrula stage & $8: 44$ to I I:44 & $7: 46$ to $14: 44$ & $\begin{array}{l}8: 35 \text { to } 22: 20 \\
21.6^{\circ} \mathrm{C}\end{array}$ & $\begin{array}{l}8: 30 \text { to } 15: 36 \\
23.3^{\circ} \mathrm{C}\end{array}$ & $\begin{array}{l}9: 30 \text { to } 15: 30 \\
23.8^{\circ} \mathrm{C}\end{array}$ \\
\hline 6 & Neurulation stage & $\mid \mathrm{I}: 59$ to $12: 5 \mid$ & $15: 45$ to $17: 45$ & $\begin{array}{l}26: 00 \\
20.6^{\circ} \mathrm{C}\end{array}$ & $\begin{array}{l}16: 30 \text { to } 18: 30 \\
23.4^{\circ} \mathrm{C}\end{array}$ & $\begin{array}{l}16: 30 \text { to } 18: 30 \\
23.9^{\circ} \mathrm{C}\end{array}$ \\
\hline 7 & Organ differentiation & I8: I | to $95: 07$ & $\mid 8: 13$ to $41: 3 \mid$ & $\begin{array}{l}28: 00 \text { to } 50: 00, \\
24.0^{\circ} \mathrm{C}\end{array}$ & $\begin{array}{l}19: 30 \text { to } 50: 52 \\
24.4^{\circ} \mathrm{C}\end{array}$ & $\begin{array}{l}19: 30 \text { to } 57: 34, \\
23.6^{\circ} \mathrm{C}\end{array}$ \\
\hline 8 & Movement detection & $31: 20$ & $29: 00$ & & $\begin{array}{l}32: 26 \\
24.8^{\circ} \mathrm{C}\end{array}$ & $\begin{array}{l}30: 30 \\
23.8^{\circ} \mathrm{C}\end{array}$ \\
\hline 9 & Heart beat & $36: 30$ & $38: 02$ & & $4 \mathrm{I}: 28,26^{\circ} \mathrm{C}$ & $\begin{array}{l}40: 54 \\
24.1^{\circ} \mathrm{C}\end{array}$ \\
\hline 10 & Hatching stage & $109: 15$ & $49: 44$ & $\begin{array}{l}70: 00 \\
20.6^{\circ} \mathrm{C}\end{array}$ & $54: 30,26.3^{\circ} \mathrm{C}$ & $\begin{array}{l}61: 38 \\
23.4^{\circ} \mathrm{C}\end{array}$ \\
\hline
\end{tabular}

Table 5 Comparison of several developmental traits of L. platydorsus, B. trevelyani, L. intermedius, L. brevicephalus and L.megastoma

\begin{tabular}{|c|c|c|c|c|c|}
\hline $\begin{array}{l}\text { Developmental } \\
\text { traits }\end{array}$ & $\begin{array}{l}\text { L.platydorsus } \\
\text { (this study) }\end{array}$ & $\begin{array}{l}\text { B. trevelyani } \\
\text { (Cambray, 1985) }\end{array}$ & $\begin{array}{l}\text { L.intermedius(Ryabov, } \\
\text { 2002) }\end{array}$ & $\begin{array}{l}\text { L.brevicephalus } \\
\text { (Belay et al., 2017) }\end{array}$ & $\begin{array}{l}\text { L.megastoma } \\
\text { (this study) }\end{array}$ \\
\hline $\begin{array}{l}\text { Eggs, demersal and } \\
\text { adhesive }\end{array}$ & Yes & Yes & Yes & Yes & Yes \\
\hline $\begin{array}{l}\text { Fertilized egg } \\
\text { diameter }(\mathrm{mm})\end{array}$ & 3.29 & 1.5 & 3.0 & 3.03 & 2.63 \\
\hline Hatching time & $\begin{array}{l}61 \mathrm{~h}+38 \mathrm{~min} \text { at } \\
23.4^{\circ} \mathrm{C}\end{array}$ & $67 \mathrm{~h}$ at $17-19^{\circ} \mathrm{C}$ & $70 \mathrm{~h}$ at $20.6^{\circ} \mathrm{C}$ & $\begin{array}{l}50 \mathrm{~h}+30 \mathrm{~min} \text { at } 25- \\
25.8^{\circ} \mathrm{C}\end{array}$ & $\begin{array}{l}54 \mathrm{~h}+30 \mathrm{~min} \text { at } \\
26.3^{\circ} \mathrm{C}\end{array}$ \\
\hline \multicolumn{6}{|l|}{ Length $(\mathrm{mm})$ at } \\
\hline a) hatching & 6.4 & 3.7 & 7.8 & 5.1 & 5.7 \\
\hline b) yolk absorption & 8.9 & 7.1 & & 9.6 & 10.5 \\
\hline $\begin{array}{l}\text { c) pelvic bud } \\
\text { formation }\end{array}$ & 13.5 & 10.6 & & 14.8 & 12.7 \\
\hline \multicolumn{6}{|l|}{ Larval behavior } \\
\hline $\begin{array}{l}\text { a) active upward, } \\
\text { passive sinking }\end{array}$ & Yes & Yes & & Yes & Yes \\
\hline b) adhere to objects & Yes & Yes & & Yes & Yes \\
\hline c) pelagic larvae & Some & Few & & Some & Some \\
\hline $\begin{array}{l}\text { d) cluster together on } \\
\text { the substratum }\end{array}$ & Yes & Yes & & Yes & Yes \\
\hline
\end{tabular}

Citation: Abdissa B, Getahun A, Dejen E. Embryonic and larval development of Labeobarbus megastoma and Labeobarbus platydorsus(pisces: cyprinidae) in lake tana (Ethiopia). J Aquac Mar Biol. 2020;9(5):191-20I. DOI: 10.15406/jamb.2020.09.00295 
Fertilized eggs of L. megastoma and L. platydorsus were transparent and unfertilized that were opaque and white. Then live eggs changed color to yellowish. This change indicates the beginning of embryonic development. The perivitelline space in the fertilized eggs of the two species are medium sized. It is believed that in some species of fish larger perivitelline space contributes to the defense against environmental adversities and ensures higher survival rates in lotic environments. ${ }^{30,31}$ Thus, the characteristics of L. megastoma and L. platydorsus eggs fit this preferred reproduction site and time: in high water volume rainy season with highly oxygenated and gravel filled spawning spots.

The fertilized eggs of L. megastoma and L. platydorsus have twolayered membrane (Figure $3 b$ ); the outer membrane is the secondary egg envelope which is flexible and adhesive. Therefore, the egg can easily adhere to rocks and gravel and plants in water. At the hatching stage, the outer membrane of the egg becomes thinner until it finally breaks, facilitated by the dissolution by the hatching enzyme and embryonic movements. ${ }^{32}$

First cleavage of eggs of L. megastoma and L. platydorsus were observed similarly at about $1 \mathrm{~h}$ and $30 \mathrm{~min}$ post-fertilization at the water temperature of 23.5 and $23.1^{\circ} \mathrm{C}$. They are, slower than top mouth gudgeon $P$. parva $a^{22}$ which took only $54 \mathrm{~min}$ at $24 \pm 1^{\circ} \mathrm{C}$ and faster than white suker Catostomus commersoni ${ }^{26}$ where the first cleavage furrow was visible within $2 \mathrm{hr}$ and $18 \mathrm{~min}$ post-fertilization. These variations might be attributed to species difference and incubation temperature.

In L. megastoma and L. platydorsus, first five cleavages that divided the blastodisc into 32 blastomeres were regular in size (Plate 1F; Plate 2.7). This process is similar with that of Trichogaster fasciata (Hossen et al., 2014). ${ }^{33} \mathrm{Hall}^{34}$ revealed that in most fish species the blastomeres are regular in size and shape. Time taken from first cleavage to early morula stages of L. megastoma and L. platydorsus ranged from 1:00 to $3: 30 \mathrm{~h}$ and $1: 30$ to $4: 30 \mathrm{~h}$, respectively. Whereas in the case of white suckers, the time range was longer, which was from 3:07 to $13: 50 \mathrm{~h}^{26}$ but similar duration with that of L. megastoma, as was reported in top mouth gudgeon, which ranged between $54 \mathrm{~min}$ and 3:30h.

Early blastula in L. megastoma and L. platydorsus were observed at $5 \mathrm{~h}$ and $30 \mathrm{~min}$ and $6 \mathrm{~h}$ and $37 \mathrm{~min}$, respectively. According to Arezo et al. ${ }^{35}$ teleost gastrulation is morphologically characterized by the presence of a germ ring. In L.megastoma and L. platydorsus gastrulation was observed at $8 \mathrm{~h}$ and $30 \mathrm{~min}$ and $9 \mathrm{~h}$ and $30 \mathrm{~min}$, respectively. Thirty percent epiboly in $L$. megastoma and $L$. platydorsus were beginning at $12 \mathrm{~h}$ and $12 \mathrm{~h}$ and $30 \mathrm{~min}$, respectively. Contrary to this, epiboly in C. commersoni started later, at $23 \mathrm{hr}$ and 40min. Afterwards, L. megastoma and L. platydorsus embryos reached the somite stage, which continued until $35 \mathrm{~h}$ and $36 \mathrm{~h}$ and $30 \mathrm{~min}$, respectively. L. megastoma and L. platydorsus attained the pre-hatching stage near to $50 \mathrm{~h}$ and $59 \mathrm{~h}$, respectively. The main morphological and behavioral characteristic of pre-hatched embryos are the otic capsule, distinguished three brain vesicles (front, mid and hind brain), primordial pectoral fins, tail, heart vibration, conspicuous muscular contraction and demonstrations of twisting movements inside the egg capsule. The same characters were found in different fish species described by Hossen et al, ${ }^{33}$ Puvaneswari et al. ${ }^{6}$ and Osman et al. ${ }^{36}$

Embryonic development of L. megastoma and L. platydorsus is like other freshwater teleosts. The organs of L. megastoma and $L$. platydorsus were almost developed before hatching, which is like H. maculatus, ${ }^{37}$ P. guichenoti ${ }^{38}$ and P. parva. ${ }^{22}$ Development event from egg fertilization to heartbeat phase took about $42 \mathrm{~h}$ and $41 \mathrm{~h}$ and hatching begins at about $54 \mathrm{~h}$ and $62 \mathrm{~h}$ later in L. megastoma and $L$. platydorsus, respectively. A similar long time, about 73 and $75 \mathrm{~h}$, from the heartbeat stage to hatching were also reported in $P$. parva ${ }^{22}$ and Siniperca chuatsi. ${ }^{38}$ From the completion of the organ differentiation to hatching, the embryo remained in the membrane for a long time, which was described as a phenomenon named "delayed hatching". 40 This phenomenon is likely to be an evolutionary strategy to enhance the ability of the larvae to adapt to their environment immediately after hatching.

The timing of hatching was different even among the eggs fertilized at the same time and developed under the same conditions. Egg incubation ranged between 54 and 65 hours at $26.3-23.4^{\circ} \mathrm{C}$ for L. megastoma and 62 to $86 \mathrm{~h}$ at $23.4-23.8^{\circ} \mathrm{C}$ for L. platydorsus. Hossain et al. ${ }^{41}$ observed hatching period between 16 and 18 hours at $27-28^{\circ} \mathrm{C}$ for the medium carp and Labeo bata. Udit et al ${ }^{142}$ reported the egg incubation of Puntius sarana that ranged between 15 and 16 hours at $26.5-28.5^{\circ} \mathrm{C}$. Mc Elman \& Balon ${ }^{26}$ observed a prolonged hatching period in white suckers which ranged between 131 and $151 \mathrm{~h}$ at $15.0-15.2^{\circ} \mathrm{C}$. This phenomenon was also observed in Esoxlucius Linnaeus, ${ }^{43}$ H. maculatus ${ }^{37}$ and P. guichenoti ${ }^{44}$ According to previous studies, water temperature, dissolved oxygen, $\mathrm{pH}$, light and hereditary variation can influence the speed of fish embryo development. ${ }^{45,46}$ Hatching timing may also depend on the size of the eggs, because the yolk material is frequently correlated with the duration of prehatching development. ${ }^{47}$

Influence of external environmental conditions on the embryonic development still needs to act through gene expression and regulation. So, the difference in speed of L. megastoma and L. platydorsus embryonic development may also be regarded as a strategy to imprint on unique combination of environmental factors that triggers homing behavior of the upcoming spawning migration.

Rotation of embryos was a commonly observed phenomenon during the embryonic development. $\mathrm{Zhu}^{25}$ found that the embryo rotation of Clarias fuscus (Lacepède, 1803) began in the blastula phase, whereas Zhang ${ }^{48}$ reported that the embryo rotation of Branchiostoma belcheri (Gray, 1847) began during the neurula phase. $\mathrm{Gu}^{38}$ and $\mathrm{He}^{49}$ reported that the embryo rotation in Erythro culterilishaeformis, ${ }^{37}$ Botiasuperciliaris (Günther, 1892) began in the pre-hatching stage and Zhu et al. reported that the rotation of embryos of $P$. parva was observed in the blastula stage. The rotation of embryos of L. megastoma and L. platydorsus were observed in the neurulation stage in our study. Therefore, the timing of the occurrence of embryonic rotation varies among fishes.

The size of freshly hatched larvae of L. megastoma and $L$. platydorsus were 5.6 to 5.8 and 6.2 to $6.5 \mathrm{~mm}$, respectively. Whereas in Puntius sarana and common carp the size was smaller, 3.0 to $3.5 \mathrm{~mm}$ and 4.8 to $5.0 \mathrm{~mm} \cdot{ }^{27,42}$ Immediately after hatching larvae remained immobile at the bottom of the aquarium. A series of significant changes in the external morphology, and some internal organs, were seen after hatching, during the larval development.

The larvae of L. megastoma and L. platydorsus reached a size of $7.5 \pm 0.09$ to $8.15 \pm 0.05 \mathrm{~mm}$ and $7.5 \pm 0.08$ to $8.2 \pm 0.11 \mathrm{~mm}$ between 60 and $96 \mathrm{~h}$, respectively after hatching. These variations may be caused by bulk of eggs and their diameters that are positively correlated with larval length and weight at hatching. ${ }^{50}$

Within the first 3-4 days of hatching, the larvae were inactive. Short span of horizontal swimming was observed across the bottom of the glass aquarium. During the yolk-sac larva period, only the pectoral fins could be seen, and the larva's ability of swimming was 
very limited. The pectoral fins were formed before hatching, followed by the caudal fin, dorsal fin and anal fin forming in that order after the hatching, while the ventral fins were formed last. They started to swim freely on day 10 , and this is attributed to the development of gas bladder. Although larvae of many fishes exhibit two swimming strategies, physostomous at larval stages and physoclistous as adults, ${ }^{51,52}$ L. megastoma and L. platydorsus had only physoclistous type of gas bladder. The gas bladder was developed within 7-10 days, and the larvae started to swim freely in any direction. There is also presence of well-developed serial muscle bundles (myomeres) which help the larvae to swim actively below the surface before the formation of gas bladder.

L. megastoma and L. platydorsus absorbed yolk sac within 7 to 10 days at water temperature of $23.0-24.2^{\circ} \mathrm{C}$. The first swim bladder was formed about two days after hatching, then aerated gradually in subsequent days, while the second swim bladder appeared about nine days after hatching. Then, larvae started feeding exogenously before complete absorption of the yolk sac (Figure 6c). The complete disappearance of the yolk sac ten days after hatching marked the metamorphosis of larvae into fry. The yolk absorption period was 3-4 days for Indian major carps at water temperatures $24-31^{\circ} \mathrm{C} .{ }^{27}$ According to Uditet et al. P. sarana absorbed yolk sac within 60 to 65hours at water temperature of 27.0 to $28.5^{\circ} \mathrm{C}$ and Zhu et al. reported that in P. parva complete disappearance of the yolk sac occurred six days after hatching at $24 \pm 1{ }^{\circ} \mathrm{C}$. These results indicate that the yolk absorption period is a species-specific characteristic, and depends on water temperature. As the yolk sac of L. megastoma and L. platydorsus were bigger than that of $P$. sarana Indian major carps and $P$. parva, it was absorbed at a slower rate. Forty days after hatching, all fins were formed, a few fin folds existed on the ventral and caudal peduncle and the morphology of the fry was very like the adult fish.

The pigmentation appeared on head (heart-shaped pigment pattern), two distinct rows of pigment appeared along the dorsal surface of trunks; also pigment cell appeared behind the eyes, and a caudal spot occurred at seven days post hatching (Figure 6b). The same pigmentation pattern was described for endangered African barb, Barbus trevelyani. However, the developmental rate of pigmentation patterns of barbs significantly differs seven days in. L. megastoma and L. platydorsus vs. 69 days in B. trevelyani ${ }^{25}$

\section{Conclusion}

Developmental studies would enable us to understand early embryonic developmental stages and first feeding of L.megastoma and L.platydorsus, which can be utilized to improve rehabilitation efforts to save the endangered Labeobarbus fish species of Lake Tana. The information obtained from this study will be useful to cover gaps in early life history, first feeding and ontogeny of L.megastoma and L.platydorsus and such information could be beneficial for comparative studies and as a basis for further studies on the ontogeny of these two species.

\section{Acknowledgements}

We would like to thank Dr. Shkil for his unreserved assistance during experiments and who read the manuscript and made valuable remarks. We acknowledge the support of Bahir Dar Fisheries and Other Aquatic Life Research Center (BFLARC) in providing the facilities for the study and Critical Ecosystem Partnership Fund (CEPF) (grant no.63341) for its financial support.

\section{Conflicts of interest}

Embryonic and larval development of Labeobarbus megastoma and Labeobarbus platydorsus (Pisces: Cyprinidae) in Lake Tana (Ethiopia) was conducted by the authors as part of $\mathrm{PhD}$ research work.

\section{References}

1. Borcato FL, Bazzoli N, Sato Y. Embryogenesis and larval ontogeny of the Pirugordura, Leporinuspiau (Fowler) (Pisces, Anostomidae) after induced spawning. Revista Brasileira de Zoologia. 2004;21(1):117-122.

2. Simon PT Robert W. Reproductive biology and early life history of fishes in the Ohio river drainage system IV. Taylor and Francis group. 2006.

3. Shkil FN, Dzerzhinskii KF, Belay Abdissa, et al. Notes on the breeding of large Lake Tana barbs (Labeobarbusspp.) in nature and laboratory. Ethiop J Biol Sci. 2017;16:149-170.

4. Belay A, Abebe G, Eshete D. Artificial propagation in Labeobarbus brevicephalus (pisces: Cyprinidae) Lake Tana. Aquaculture. $2020 ; 521,735063$

5. Meijide, F.J, Guerrero, G.A Embryonic and larval development of a substrate brooding cichlid Cichlasomadimerus (Heckel, 1840) under laboratory conditions. Journal of Zoology. 2000;252(4):481-493.

6. Puvaneswari, S, Marimuthu, K, Karuppasamy, R, et al. Early embryonic and larval development of Indian catfish, Heteropneustes fossils. EurAsian Journal of Bio Sciences. 2009;3(1):84-96.

7. Tomasson T, Cambray JA, Jackson PBN. Reproductive biology 'of four large riverine fishes (Cyprinidae) in a man-made lake, Orange River, South Africa. Hydrobiologia.1984;112:179-195.

8. Skelton PH. A complete guide to the freshwater fishes of southern Africa 2nd edn, Southern Book Publishers, South Africa, 2001. p. 388

9. deGraaf M. Lake Tana'spiscivorousBarbus (Cyprinidae, Ethiopia): Ecology, Evolution, Exploitation. PhD Thesis, Wageningen University, Wageningen. 2003.

10. Palstra AP, de Graaf M, Sibbing FA. Riverine spawning and reproductive segregation in a lacustrine species flock, facilitated by homing? Anim Biol. 2004;54(4):393-415.

11. deGraaf M, Nentwich ED, Osse JWM, et al. Lacustrine spawning: is this a new reproductive strategy among "large" African cyprinid fishes? Journal of Fish Biology. 2005;66:1214-1236.

12. Nagelkerke LAJ, Sibbing FA, Boogaart JGM, et al. The barbs (Barbus spp.) of Lake Tana: a forgotten species flock? Environmental Biology of Fishes.1994;39:1-22.

13. Nagelkerke LAJ, Sibbing FA. The large barbs (Barbusspp., Cyprinidae, Teleostei) of Lake Tana (Ethiopia), with a description ofa new species, Barbusosseensis. Nether J Zool. 2000;50:179-214.

14. de Graaf M, van Zwiete, PAM, Machiels MAM, et al. Vulnerability to a small-scale commercial fishery of Lake Tana's (Ethiopia) endemic Labeobarbus compared with African catfish and Nile tilapia: An example of recruitment-overfishing? Fisheries Research. 2006;82: 304-318.

15. Wassie Anteneh, Abebe Getahun, Eshete Dejen, et al. Spawning migrations of the endemic Labeobarbus (Cyprinidae, Teleostei) species of Lake Tana, Ethiopia: status and threats. J Fish Biol. 2012;81:750-765.

16. Snoeks J, Harrison IJ, Stiassny MLJ Chapter 3: The status and distribution of freshwater fishes. IUCN AFR2011_ppi-xiii_Intro pages. indd. 2011.

17. Ryabov IN. Ecological and Morphological Features in Development of BarbelBarbusintermedius Riippell, 1836, from Lake Tana (Ethiopia), $J$ Ichthyol. 2002;42, 787-797. 
18. Alekseyev SS, Dgebuadze Yu, Yu Mina, et al. Small "Large Barbs" Spawning in Tributaries of Lake Tana: What Are They? Folia Zool. 1996;45 suppl. I. p. 85-96.

19. Dzerzhinskii KF, Shkil FN, Belay Abdissa, et al. Spawning of large Barbus (Barbusintermediuscomplex) in a small river of the Lake Tana Basin (Ethiopia) and relationships of some putative species. J Ichthyol. 2007;47:639-646.

20. 20. Carson FL, Hladik C Histotechnology: A Self-Instructional Text 3rd edn Hong Kong: American Society for Clinical Pathology Press. 2009.p. 19.

21 Webb GN, Byrd, RA Simultaneous Differential Staining of Cartilage and Bone in Rodent Fetuses: An Alcian Blue and Alizarin Red S Procedure without Glacial Acetic Acid. Biotec. And Histo. 1994;69(4):181-185.

22 Zhu DM, Yang K, Ning S, et al. Embryonic and larval development of the topmouth gudgeon, Pseudorasboraparva(Teleostei: Cyprinidae). Zoologia. 2018; 35: 22162.

23 Cambray JA. Early development and larval behavior of a minnow, Barbusanoplus (Pisccs: Cyprinidae). S Afr JZool. 1983;18: 331-336.

24 Cambray JA. Early ontogeny of Labeocupensis (Pisces: Cyprinidae). $S$ Afr J ZOO. 1985;20 (4):190-196.

25 Zhu ZY. Embryonic development of Clariasfuscus(Teleostei, siluriformes). ActaHydrobiologicaSinica. 1982;4:445-454.

26 McElman JF, Balon EK. Early ontogeny of walleye, Stizostedionvitreum, with steps of saltatory development. Env Biol Fishes. 1979;4 : 309-348.

27 Woynarovich, E, Horvath, L. The artificial propagation of warm-water fin fishes: A manual for extension. FAO Fisheries Technical Paper No. $201 \mathrm{FIR} / \mathrm{T} 201.1984$.

28 Watson CA, Chapman FA Artificial incubation of fish eggs. Fact Sheet FA-32, Institute of Food and Agricultural Science, University of Florida Extension. 2002

29 Andrade-Talmelli EF, Kavamoto ET, Romagosa E, et al. Embryonic development of the "piabanha,"Brycon insignis (Steindachner, 1876) (Pisces; Characidae). Boletim do Instituto de Pesca. 2001;27: 21-28.

30 Lake JS. Rearing experiments with five species of Australian freshwater fishes. Morphogenesis and ontogeny. Marine \& Freshwater Research.1967;18: 155-173.

31 Matsuura, Y. Egg dévelopment of scaled sardine HarengulapensaolaeGoode \& Bean (Pisces Clupeidae). Boletim Do InstitutoOceanográfico. 1972;21: 129-135.

32 Xu GC, Tang X, Zhang CX, et al. First studies of embryonic and larva development of Coilianasus(Engraulidae) under controlled conditions. Aquaculture Research. 2011;42 (2):593-601.

33 Hossen MS, Reza AH, Rakhi SF, et al. Observation of embryonic and early larval development of striped gourami, Trichogasterfasciata (Perciformes :Osphronemidae). EurAsian Journal of BioSciences. 2014;8: 61-70.

34 Hall, T.E Pattern formation. In: Finn, R.N, Kapoor BG, editors, Fish larval physiology, Science Publishers, Enfield, New Hampshire. 2008;3-25.

35 Arezo, M.J, Pereiro, L, Berois, N Early development in the annual fish Cynolebiasviarius. Journal of Fish Biology. 2005;66: 1357-1370.

36 Osman AGM, Wiertz S, Mekkawy IA, et al. Early development of the African catfish Clariasgariepinus focusing on the ontogeny of selected organs. Journal of Applied Ichthyology. 2008;24(2):187-195.
$37 \mathrm{Gu} \mathrm{RB}$, Wen $\mathrm{HB}, \mathrm{Xu} \mathrm{GC}$, et al. Preliminary observation on the embryonic development and morphology of the yolk-sac larva of Hemibarbus maculates bleeker, Journal of Zhejiang Ocean University (Natural Science). 2006;25 (4):373-378.

$38 \mathrm{Gu} \mathrm{ZM}, \mathrm{Zhu}$ JJ, Jia YY, et al. Research on embryonic and post embryonic development of Erythroculterilishaeformis Bleeker of Taihu Lake. Journal of Fishery Sciences of China. 2008;15 (2):204-214.

39 Mi GQ, Lian QP, Wang YC, et al. Observation on embryonic development of crossbreed F1 by Sinipercascherzeri $(+) \times$ Sinipercachuatsi $\left({ }^{\Uparrow}\right)$. Journal of Zhejiang Ocean University(Natural Science). 2009;28(3):264-269.

$40 \mathrm{Wu}, \mathrm{LX}$, Zou, B The morphologic observation of embryonic development of SinipercascherzeriSteindachner in Biliuhe reservoir. Fisheries Science. 1993;12: 5-8.

41 Hossain QZ, Hossain AM, Parween S. Breeding performance and nursery practices of Labeobata (Hamilton-Buchanan). Scientific World. 2007;5 (5):40-45.

42 Udit UK, Reddy AK, Kumar P, et al. Induced breeding, embryonic and larval development of critically endangered fish Puntius sarana (Hamilton, 1822) under captive condition. Journal of Animal \& Plant Sciences. 2014; 24 (1):159-166.

43 Qiao DL, Li SF, Ling QF, et al. Development of embryo and yolk-sac stage larva of white spot pike, Esoxlucius. Journal of Shanghai Fisheries University. 2005;14 (1):12-18.

$44 \mathrm{Gu} \mathrm{RB}, \mathrm{Xu} \mathrm{GC}$, Wen $\mathrm{HB}$, et al. Embryonic and post-embryonic development of Paracanthobramaguichenoti. Journal of Fishery Sciences of China. (2008 a);15(3):414-424

45 Cussac VE, Matkovic M, Maggese M.C Embryonic development of Rhamdiasapo (Valenciennes, 1840) Eigenmann and Eigenmann, 1888 (Pisces, Pimelodidae) II. Average organogenesis, late organogenesis and hatching. Brazilian Journal of Biology. 1985; 45:149-160.

46 Asoh, K, Yoshikawa, T The role of temperature and embryo development time in the diel timing of spawning in a coral-reef damselfish with high-frequency spawning synchrony. Environmental Biology of Fishes. 2002;64(4):379-392.

47 Adriaens D, Vandewalle, P. Embryonic and larval development in catfish Arratia, G, Kapoor, A.S, Chardon, M \&Diogo, R, editors, Enfield, NH: Science Publisher, Inc. 2003. 639-666 p.

48 Zhang QJ. Taxonomy of Genus Branchiostomain Xiamen waters and continuous breeding of two Lancelets in the laboratory. $\mathrm{PhD}$ thesis, China, Fujian: Xianmen University. 2007.

$49 \mathrm{He} \mathrm{B}$, Chen XJ, Wen $\mathrm{T}$, et al. Embryonic development of Botiasuperciliaris. Southwest China Journal of Agricultural Sciences. 2014;27 (3):1332-1336.

50 Pepin P. Effect of temperature and size on development, mortality, and survival rates of the pelagic early life history stages of marine fish. Canadian Journal of Fisheries and Aquatic Sciences. 1991;48: 503-518.

51 Boglione C, Paulo G, Koumoundouros G, et al. Skeletal anomalies in reared European fish larvae and juveniles. Part 1: normal and anomalous skeletogenic processes. Reviews in Aquaculture. 2013;5 (Suppl. 1), S99-S120.

52 Belay Abdissa, Abebe Getahun, Eshete, Dejen. Embryonic and larval development of an endemic Lake Tana barb, Labeobarbusbrevicephalus (Teleostei: Cyprinidae). Ethiop J Biol Sci. 2019;16(1):63-82. 